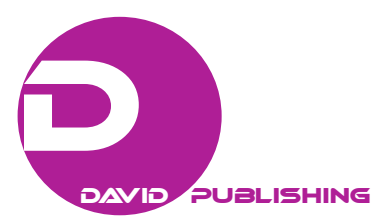

\title{
Knowledge Acquisition in Small and Medium Businesses
}

\author{
Beata Glinkowska \\ University of Lodz, Lodz, Poland
}

\begin{abstract}
This article applies to the process of organizational knowledge acquisition by managers and specialists with the possession of manager license. The theoretical part explains: concepts of knowledge, knowledge management, knowledge sources, and the step of creating and acquiring knowledge. The research part focuses on the presentation and analysis of obtained results of research performed by the author.
\end{abstract}

Keywords: small business, enterprise, manager, knowledge, absorption of knowledge, knowledge acquisition

\section{Introduction}

The problems associated with the process of knowledge management in present organizations, including those from the small and medium-sized business, are often undertaken in Poland and worldwide literature. The subject has been described by many researchers, from different points of view-management, economics, psychology, accounting, and sociology. Despite such a broad research of the topic, it is still alive, but not studied well. We live in the time of a knowledge-based economy (KBE), so the search for new opportunities to acquire knowledge, its application, and use, is an important issue. In the research area of the article's author, acquisition process (absorption) of knowledge in the sector of small and medium-sized enterprises (SME) in Poland, is the main interest.

\section{Methodology of the Research}

The study with distinctive characters was carried out on a sample of 30 companies from the sector of SME in the Lodz region (Poland). The surveyed companies represent different sectors (e.g. textile, food, metal, and transport). In order to conduct the interview, 40 managers of different levels and specialists from various fields and functions (e.g. supply, logistics, HR, and IT) were chosen from selected SME. The research was carried out in the framework of the Faculty of Management, in the Department of Management at the University of Lodz. They represent a continuation of studies concerning the preparation of Polish enterprises to enter the foreign markets. At this stage, an attempt to examine how the process of knowledge acquisition goes in small and medium-sized enterprises was made. The research tool was a questionnaire, focused mainly on getting answers to the questions about sources of knowledge, organizational barriers, and difficulties in the process of acquiring knowledge by the participants of the organization. The purpose of this article is to present the results of research related to the knowledge acquisition in the SME. The hypothesis is that the most common sources of organizational knowledge in the process of absorption are following: employees, the Internet, and trainings; and the most important barriers in the same process are: lack of ability to acquire the knowledge independently, no

Beata Glinkowska, Ph.D., Faculty of Management, University of Lodz, Lodz, Poland.

Correspondence concerning this article should be addressed to Beata Glinkowska, Więckowskiego 30/44 street, 90-728 Łódź, Poland. 
motivation, and high costs. The research is a continuation of the study starting in 2014. Parallel to these, studies in the area of the internationalization of Polish enterprises are being conducted.

\section{Literature Review}

\section{Knowledge-The Concept and Essence}

Knowledge is deemed to be the key resource of an organization and a key factor in the success of any business, regardless of size or industry type. Skrzypek highlights that the quality of the knowledge and acquired information testifies business intelligence (Skrzypek, 2013). It has an impact on the company's mission, objectives, vision, strategies, methods, and technologies. Drucker notices that the material resources of the organization went to the wayside (Drucker, 1999). According to many sources, the basis of knowledge is both: data and information (Brdulak, 2005). The data are numbers and events, which are the constituent elements of information (Grudzewski \& Hejduk, 2004). The data can be informal and unorganized; however it can also be ordered and formalized, and "tailored" for the user's needs becomes an information. Information is registered, grouped, collated, and interpreted form, from the point of view of the particular situation (Galata, 2004). Knowledge is a specific type of organization resource, which comes up along as it is used (in opposition to the other organization resources) (Galata, 2004). Information is defined as everything that anyone knows about in a particular field or a particular subject (Penc, 1994). The word "information" comes from the Latin informatio (explanation, image, notification); and knowledge is a "supply of messages from a particular area" (PWN Ecyclopedies [in:] http://encyklopedia.pwn.pl/haslo/3914686/informacja.html). The Polish Dictionary says that the information is understood as a "message about something" (Bańko (Ed.), 2005), but also "data being processed by a computer" (Drucker, 1999). Knowledge is explained as the "general information acquired through learning, understanding of something, awareness of something". In the literature there is a consensus with the fact that the data are the basis of creating information, and this makes the organizational knowledge, which builds up the organizational wisdom. P. Drucker, one of the first researchers in this area, has emphasized the importance of knowledge in the economy; he defined it as an effective use of information (Drucker, 1999). Koźminski refers the knowledge to the formation of competitive advantage, noting that transformed prior knowledge, becomes a secondary knowledge, which in the process of knowledge management can give an advantage in the market (Koźminski, 2005). An interesting definition of knowledge is given by A. Tiwan. From his point of view, it is a mix consisting of contextual experiences, values, skills, information, understanding, and assimilation of new information (Tiwan, 2003), to which the article's author agrees. Moving on to the term of organizational knowledge types, it is comprehensively presented by B. Mikuła, who has upheld the knowledge components such as core of a personalized knowledge, personalized knowledge itself, codified knowledge, well-established knowledge, up to the organizational knowledge, which determines the key competencies (Mikuła, 2005). With the core modification of personalized knowledge to the codified is possible. Analysis of existing approaches, defining the organizational knowledge, indicates that they can be divided into three groups:

- Focusing on knowledge management process: capturing, collecting, customization, localization, use, sharing, and storing of the knowledge (Quintas, Lefrere, \& Jones, 1997);

- Focusing on strategy (business approach) (Schultze \& Stabel, 2004);

- Focusing on socio-cultural aspects of knowledge management (Schlegelmilch \& Penc, 2002).

The author's opinion is that it is impossible to put issues of organizational knowledge on only one of these 
groups. It belongs to all of those groups; therefore it is the business process, where the strongest link is the man with his knowledge.

\section{Knowledge Management-Essence, Components, and Steps}

The concept of knowledge management also has many definitional approaches regarding its essence, components, and steps. Among them, often the most developed (by advisory and consulting companies) can be listed, as they are based primarily on the use of knowledge as a source of competitive advantage of the company. According to Perechuda (2005), "knowledge management is a process by which it is possible to continuously execute the functions of management" (p. 219) and "management in terms of the knowledge-based economy" (p. 219). Referring to the Encyclopedia of Management, the definition explains the process as "general actions for the identification, preservation, dissemination and use of knowledge overt and covert of the company staff, mainly for increasing the efficiency and effectiveness of employees actions" (Encyclopedia of Management [in:] http://mfiles.pl/pl/index.php/Zarządzanie_wiedza). Skyrme sees knowledge management through the prism of the stages of the process: creating, gathering, organizing, diffusing, use, and exploitation (Skyrme, 1999). On the other hand, Sarvary emphasizes that knowledge management is a business process by which companies use organizational knowledge (Sarvary, 1999). Similarly to Skyrme, understanding of the process of knowledge management can be found in the book Knowledge management in organizations (Probst, Raub, \& Romhardt, 2002). The authors have developed a knowledge management scheme, which can be found by following steps:

- Acquisition of knowledge,

- Locating of knowledge,

- The preservation of knowledge,

- The use of knowledge,

- Sharing of the knowledge (dissemination),

- The development of knowledge (Probst et al., 2002).

Jashapara (2006) proposed his own approach in the process of knowledge management cycle. His approach is based on the following specific processes: knowledge discovery, knowledge generation, application of knowledge, valuing knowledge, and its dissemination (Probst et al., 2002). E. Skrzypek (2013) defines the knowledge management as a combination of: understanding and experience, overt and covert knowledge, and physical and social technology (Urbańczyk (Ed.), 2001). From the economic point of view, the essence of this process is presented by Wiig (1993), saying that it is a systematic and thoughtful creation and application of knowledge in order to maximize the efficiency of the business and achievement of a profits on the resources of knowledge (Wiig, 1993).

Generally, in a multitude of definitions, they can be divided into two paths accordingly by the approach of the knowledge management process: (a) information systems, where the key role is an information management and technical-technological support and (b) a management of human resources in the organization (Jashapara, 2006). From the point of view of the subject of this paper, the author combines the two paths in the process of knowledge management, especially taking into account the stage of acquisition.

\section{Sources of Knowledge and Knowledge Creation Stages}

Acquiring knowledge is often called absorption (Polish Language Dictionary). The word comes from the Latin absorptio and means to imbibe of something (PWN Encyclopedies). This is the initial step in the process 
of knowledge management. The basic conditions that are conducive to the process of acquisition and creation of knowledge in organizations include mainly appropriate organizational culture. It makes the employees engaged to the process of knowledge acquisition. A crucial role is played by managers, who through the attitude, style of management, and appropriate systems of motivation, can and should create a culture based on the knowledge. Among the basic conditions conducive to organizational knowledge acquisition, Nonaka and Takeuchi mention the following order: intention, autonomy, instability (creative chaos), redundancy, and the desired diversity (Nonaka \& Takeuchi, 2000). The resource model, also known as "sources of knowledge" model, which was created by Leonard-Barton, can be distinguished both the existence and interaction of several elements for the proper management of knowledge. Sopińska and Wachowiak (2006) say that the model of knowledge sources (above) is too firmly rooted in the realities of the industrial economy to bring any revolution in terms of knowledge creation. The more that most of the results of the organization are focused on short-term activities related to the exploitation of the existing knowledge, rather than exploration (and creating) new knowledge (Sopińska \& Wachowiak, 2006). The process of knowledge creation is supported by a number of activities and initiatives aimed to increase the amount of knowledge in the organization, needed to achieve a competitive advantage (Jaśkowiec, 2010). Kłak (2010) brings the knowledge creation process to the following activities:

- Search for new information,

- Selection of the information,

- Creating concepts, structures, and properties (Kłak, 2010).

Sarvay calls the process by which a company acquires knowledge as organizational learning (Sarvary, 1999). Morawski (2005) notes that the process of acquisition (creation) of knowledge is one of the elements of knowledge management and is part of the knowledge, which derives from internal as well as (mainly) external sources, which refers to the environment (relations with customers, suppliers, partners, etc.) (Morawski, 2005). All of the concepts of knowledge management process include and emphasize the importance of elements like the process of acquiring and creating knowledge. The author of this article deems that the acquisition and creation of knowledge are sequentially successive, but not identical, however for the simplicity in the study of these processes, they are called as a one term: absorption of knowledge.

\section{Test Results}

\section{Knowledge Absorption in the Enterprise-Analysis of the Results}

The section on research methodology has been emphasized that the research was carried out within its own statutory activities. Respondents, who are managers and specialists of different enterprises from sector of SME, were informed about the purpose of the study and about the key definitions related to the process of knowledge management, including the process of absorption of knowledge in organizations. Forty managers and specialists were interviewed and the sample was selected intentionally; some of those respondents the author knows personally, other were recommended. Only sector of SME was taken into account. All respondents answered affirmatively to the question about possessing the knowledge as a potential source of competitive advantage for the organization. Each answering person was convinced that the knowledge (specialized and general) is essential in process, project, and organization management. In the free statements they have emphasized that the knowledge has to be acquired and updated continuously. Only then is it possible to meet the demands of the market, follow the customer demands, and reach the competitive advantage, because an increased competition forces a company to develop the knowledge. 
Another part of the study was to provide respondents with prepared and randomly written sources of knowledge. Respondents were asked to evaluate the importance of different sources of knowledge absorption and frequency of their use, using the elements of subjective and objective evaluation. For this purpose, the following scale was used:

- no significant- 0

- small significant-1

- strong significant-2

- very strong significant-3

The scale was related to several key organizational processes: supply, production, sales, management, and introduction of new technologies.

The results in the rows of a table were developed as statistically most given answers (40 managers and professionals from various fields from SME sector (Table 1)).

Table 1

Sources of Knowledge (Listed only those sources that have the power of the strongest impact labeled-3)

\begin{tabular}{|c|c|c|c|c|c|}
\hline Source of knowledge & Supply & Production & Sale & Management & $\begin{array}{l}\text { Introduction of } \\
\text { new technologies }\end{array}$ \\
\hline Internet & 3 & 3 & 3 & 3 & 3 \\
\hline Top manager & 2 & 2 & 2 & 2 & 2 \\
\hline Employees & 2 & 3 & 2 & 1 & 3 \\
\hline Providers & 3 & 3 & 1 & 1 & 3 \\
\hline Customers & 3 & 3 & 3 & 2 & 3 \\
\hline Knowledge acquisition alone & 1 & 3 & 2 & 1 & 3 \\
\hline Training & 3 & 3 & 3 & 3 & 3 \\
\hline Company documentation & 2 & 2 & 2 & 2 & 3 \\
\hline Technical documentation & 2 & 2 & 1 & 1 & 3 \\
\hline Studies & 2 & 1 & 3 & 2 & 2 \\
\hline Research, analysis, reports & 3 & 3 & 3 & 3 & 3 \\
\hline Databases existing in the company & 1 & 2 & 2 & 2 & 1 \\
\hline Books, magazines, media & 3 & 2 & 2 & 2 & 3 \\
\hline Benchmarking & 2 & 3 & 3 & 2 & 3 \\
\hline Friends, family & 1 & 1 & 1 & 0 & 1 \\
\hline Contests & 0 & 1 & 1 & 1 & 2 \\
\hline Cases of Polish and foreign companies & 1 & 3 & 2 & 3 & 3 \\
\hline
\end{tabular}

Source: Own analysis.

Analyzing the results presented in Table 1, it can be noticed that the strongest influences (on the surveyed managers and specialists) on absorption of knowledge are the following sources: the Internet, trainings, research, analysis and reports; then: customers, employees, company documentation, benchmarking, cases of Polish and foreign companies (strength of influence-3). Statistically the smallest significances for the respondents have: friends and family, contests, databases existing in the company (strength of influence- 0 and 1). Subsequently, analyzing the data of the Table 1, referring to the importance of the various sources of knowledge, it can be noticed that the same sources more influence some particular processes, and less some other. The results show that: 
- For the supply process (in the process of knowledge absorption) strongest influences have: the Internet, suppliers, customers, trainings, research, analysis and reports, books, magazines and the media;

- In the production process: the Internet, suppliers, customers, independent acquisition of knowledge, trainings, research, analysis and reports, benchmarking, cases of Polish and foreign companies;

- In the sales process: Internet, customers, trainings, studies, research, analysis and reports, benchmarking;

- For the process of management: the Internet, training, research, analysis and reports, cases of Polish and foreign companies;

- In the process of new technologies introduction: the Internet, employees, suppliers, customers, independent acquisition of knowledge, training, documentation, business and technological documentation, research, analysis and reports, books, magazines and media, benchmarking, cases of Polish and foreign companies.

The expanded interview shows that the trainings are generally low assessed. The respondents emphasized that trainings are often different from their expectations. The author of this article is interested particularly in the question of workers as a source of knowledge. My studies have shown that in this case it is certainly underestimated resources. Managers note that employees do not show initiative in improving processes nor knowledge sharing, and they should be more often motivated to "show independence in thoughts and action". Since the purpose of this article was not to study the existing incentive schemes in the surveyed companies, nor to check their impact on employees' engagement, and due to the fact that the respondents hold managerial or specialists positions, the questions about wages and/or motivation bonus were not asked. The answers could be too subjective. In addition, the surveyed companies represent different industries, so the employed workers are often characterized by different licenses and skills, and hence the question of average wages would be unfounded. However, there is a presumption of serious infirmities in the system of evaluation and remuneration of employees in the surveyed enterprises.

\section{Barriers and Difficulties in the Knowledge Absorbing}

In the literature different barriers associated mainly with the process of knowledge sharing are often described. The barriers of organizational knowledge obtaining are seldom mentioned. Often, although wrongly in the opinion of the article of author, it is assumed that knowledge is widely available and anyone can reach it. Respondents, who are managers and specialists in the sector of SME, have indicated various examples of the difficulties and barriers related to the process of knowledge acquisition in the surveyed enterprises. They are presented in Table 2 below.

Table 2

Barriers and Difficulties in the Process of Absorption of Organizational Knowledge (Listed only those sources that have the power of the strongest impact labeled-3)

\begin{tabular}{ll}
\hline A kind of barrier & Impact strength \\
\hline No access to the Internet & 0 \\
No friendly IT & 3 \\
"Unsupportive" management style & 3 \\
Unwillingness of workers to self-development & 3 \\
Inability to self-knowledge acquisition & 3 \\
Unwillingness providers to share knowledge & 3 \\
Lack of commitment to the processes of the customers side & 2 \\
Lack of time for additional improvement such as courses, etc. & 3 \\
\hline
\end{tabular}


Table 2 continued

\begin{tabular}{ll}
\hline A kind of barrier & Impact strength \\
\hline High costs & 3 \\
The belief that contributes little training & 1 \\
The belief that the studies do not prepare for practice & 1 \\
Untrustworthy preparing documentation of bisiness and of technological documentation & 3 \\
Lack of ability to use sources of knowledge & 3 \\
Reluctance to performe, analyzes, and reports research & 3 \\
Lack of appropriate databases in the company & 2 \\
No of tangible publication & 3 \\
Barriers associated with the use of benchmarking & 3 \\
Information noise, uncertainty information & 3 \\
No connection with the acquisition of knowledge in the company's motivational system & 3 \\
No strategy, no objectives & 3 \\
Lack of reliable scientific studies and case studies & 3 \\
Lack of proper organization and coordination & 3 \\
\hline
\end{tabular}

Source: Own analysis.

Analyzing the data, it can be seen that the greatest impacts on the barriers formation (in the process of knowledge absorption), according to the opinion of the respondents, have following factors: lack of friendly IT, "unsupportive" management style, reluctance of workers for the self-development, the reluctance of suppliers to share the knowledge, high cost of the knowledge acquisition, lack of time for additional improvement, unreliable technological and company documents preparation, disability to use sources of knowledge, inability to self-knowledge acquisition, unwillingness to perform research, analyzes, lack of relevant databases in the company, barriers associated with the use of benchmarking, hype and uncertainty of information, lack of the connection between the knowledge acquisition and the company's incentive system, lack of strategy and clearly defined objectives, lack of reliable scientific studies and case studies, lack of organization and coordination. What is interesting is that lack of access to the Internet in the opinion of the respondents is not the main barrier in the process of acquiring knowledge; they said that in the era of computerization, the access is basically unlimited and it cannot create a barrier. Currently all of the enterprises and individuals have the Internet access, and the access can be useful in restaurants, hotels, schools, and universities.

\section{Conclusion}

The study had a pilot, distinctive character and it is a complementation to the study, carried out in 2014 . The author is aware that the results are unrepresentative. However, on this basis it can be concluded that:

(1) The Polish companies in the micro sector and SME are not prepared for the overall process of knowledge management. Even though the importance of knowledge acquisition for the competitiveness of the organization is clearly seen, it is not formal, regulated, or mandatory. It is not even systematic;

(2) The employees are underestimated source in the process of knowledge acquisition;

(3) The Internet is an important source of knowledge; however lack of the access is not the most important barrier;

(4) Research, analysis, case studies of Polish and foreign examples and customers are the most important, in the opinion of respondents, sources in the knowledge absorption; 
(5) Trainings are important sources of knowledge, from the point of view of the respondents; however in the extended interview they admit that its form and character do not give satisfying results.

The hypothesis was partially verified positively and partly falsified. The author of this paper in the past was a person in the position fulfilling a managerial functions, emphasizing the workers knowledge as the most important (in her opinion) source of knowledge in the process of organizational knowledge absorption, so it was somewhat surprising that in the Internet, as a source, went ahead of the workers knowledge.

The research will be continued in next years, as part of the statutory activity, with an extension to the internationalizing companies, and as it was highlighted in the introduction, the author carries out a parallel study on the process of Polish enterprises internationalization.

\section{References}

Applehans, W., Globe, A., \& Laugero, G. (1999). Managing knowledge. A practical web-based approach, Addison-Wesley, b.m.w. In J. J. Brdulak (Ed.), Systemy informatyczne w zarządzaniu wiedzą. E-mentor, 2(4). Retrieved from http://www.e-mentor.edu.pl/artykul/index/numer/4/id/52

Bańko, M. (Ed.). (2005). Wielki słownik wyrazów obcych. Warszawa: Wydawnictwo Naukowe PWN.

Brdulak, J. J. (2005). Zarzqdzanie wiedzq a proces innowacji produktu. Budowanie przewagi konkurencyjnej firmy. Warszawa: Szkoła Główna Handlowa.

Drucker, P. (1999). Społeczeństwo pokapitalistyczne. Warszawa: Wydawnictwo Naukowe PWN.

Encyklopedia Popularna PWN. (1982). Warszawa: Wydawnictwo Naukowe PWN. Retrieved from http://encyklopedia.pwn.pl/haslo/3914686/informacja.html7

Encyklopedia PWN. (2014). Encyklopedia PWN. Retrieved from http://encyklopedia.pwn.pl/szukaj/absorpcja.html

Encyklopedia Zarządzania. (2014). Retrieved from http://mfiles.pl/pl/index.php/Zarządzanie_wiedzą

Galata, S. (2004). Strategiczne zarzqdzanie organizacjami. Wiedza, intuicja, strategie, etyka. Warszawa: Difin.

Grudzewski, W. M., \& Hejduk, I. K. (2004). Zarzqdzanie wiedzq w przedsiębiorstwach. Warszawa: Difin.

Jashapara, A. (2006). Zarzqdzanie wiedza. Zintegrowane podejście. Warszawa: PWE.

Jaśkowiec, M. (2010). Zarządzanie wiedzą jako kluczowy czynnik sukcesu i przewagi konkurencyjnej organizacji XXI wieku. In P. Murray, and A. Myers (Eds.), The facts about knowledge, information strategy. Special report. Retrieved from http://www.info-strategy.com

Kłak, M. (2010). Zarzq̨zanie wiedzq we współczesnym przedsiębiorstwie. Wyd. Wyższej Szkoły Ekonomii i Prawa im. Prof. E. $\begin{array}{lllll}\text { Lipińskiego } & w & \text { Kielcach, } & \text { Kielce. } & \text { Retrieved }\end{array}$ http://www.wseip.edu.pl/dniw/images/pliki/pelne_teksty_ksiazek/Marcin\%20Kłak_M_Zarz_wiedza_w_przeds.pdf

Koźmiński, A. K. (2005). Zarzqdzanie w warunkach niepewności. Podręcznik dla zaawansowanych. Warszawa: Wydawnictwo Naukowe PWN.

Leonard-Barton, D. (1995). Wellsprings of Knowledge. Harvard Business School Press. Boston. In A. Sopińska, and P. Wachowiak (Eds.) (2006), Modele zarządzania wiedzą w przedsiębiorstwie, E-mentor nr 1 (14). Retrieved from http://www.e-mentor.edu.pl/artykul/index/numer/14/id/275

Mikuła, B. (2005). Geneza, przesłanki i istota zarządzania wiedzą. In K. Perechuda (Ed.), Zarzq̨dzanie wiedza w przedsiębiorstwie. Warszawa: Wydawnictwo Naukowe PWN.

Morawski, M. (2005). Ilościowe zarządzanie wiedzą podejście zachodnie. In K. Perechuda (Ed.), Zarzqdzanie wiedza w przedsiębiorstwie. Warszawa: Wydawnictwo Naukowe PWN.

Nonaka, I., \& Takeuchi, H. (2000). Kreowanie wiedzy w organizacji. Warszawa: Poltext.

Penc, J. (1994). Informacje rynkowe a sukces firmy. Marketing i Rynek, 3.

Perechuda, K. (Ed.). (2005). Zarzadzanie wiedzq w przedsiębiorstwie. Warszawa: Wydawnictwo Naukowe PWN.

Probst, G., Raub, S., \& Romhardt, K. (2002). Zarządzanie wiedzq w organizacji. Kraków: Oficyna, Ekonomiczna.

Sarvary, M. (1999). Knowledge management and competition in the consulting industry. California Management Review, 95-107.

Skrzypek, E. (2001). Wpływ zarządzania wiedzą na wartość firmy. In E. Urbańczyk (Ed.), Zarządzanie wartościq przedsiębiorstwa w warunkach globalizacji. Szczecin: Wydawnictwo Naukowe Uniwersytetu Szczecińskiego. 
Schlegelmilch, B. B., \& Penz, E. (2002). Knowledge management in marketing. Marketing Review, 1(3). DOI: http://dx.doi.org/10.1362/146934702321477208

Schultze, U., \& Stabell, C. H. (2004). Knowing what you know? Discourses and contradictions in knowledge management research. Journal of Management Stdies, 4 (41).

Skrzypek, E. (2013). Uwarunkowania zarządzania wiedzą w organizacji w społeczeństwie informacyjnym. Central European Journal of Social Sciences and Humanites, 32. Wydawnictwo Uniwersytetu Rzeszowskiego. ISSN 1898-5084.

Skyrme, D. J. (1999). Knowledge networking creating the collaborative enterprise. Oxford: Butterworth Heinemann.

Szymczak, M. (Ed.). (1981). Stownik języka polskiego. Warszawa: Wydawnictwo Naukowe PWN.

Słownik Języka Polskiego. (2015). Retrieved from http://sjp.pl/absorpcja

Sopińska, A., \& Wachowiak, P. (2006). Modele zarządzania wiedzą w przedsiębiorstwie. E-mentor, 1(14). Retrieved from http://www.e-mentor.edu.pl/artykul/index/numer/14/id/275

Quintas, P., Lefrere, P., \& Jones, G. (1997). Knowledge management: A strategic agenda. Long Range Planning. DOI: 10.1016/S0024-6301(97)90252-1

Tiwana, A. (2003). Przewodnik po zarzqdzaniu wiedzq. E-biznes i zastosowania CRM. Warszawa: Agencja Wydawnicza Placet.

Wiig, K. M. (1993). Knowledge management foundations: Thinking about thinking-How people and organizations cerate, represent, and use knowledge. TH, Arlington: Schema Press. 